\title{
Psychosocial study about the consequences of work in hospital nurses as human resource management
}

\author{
Ma José López-Montesinos
}

Objectives: To analyze the relation between psychosocial and sociodemographic variables in nursing professionals. To discover the levels of job satisfaction, psychosomatic symptoms and psychological well-being in nurses. Method: The research was conducted in a sample of 476 nurses / as from nine hospitals in the region of Murcia (Spain). An occupational health protocol was distributed among the sample participants for completion, which contained tools for measuring and describing psychosocial and sociodemographic variables. Results: Although there is no high risk for psychological problems among the sample participants, psychosomatic symptoms, job dissatisfaction, and low psychological wellbeing are present. Conclusions: The results contribute to research on the subject by identifying the presence of psychosocial disorders in nursing professionals, associated with job conditions and certain psychosocial and sociodemographic variables.

Descriptors: Psychosocial Consequences; Occupational Health; Nursing.

${ }^{1} \mathrm{PhD}$, Professor, Departamento de Enfermería, Facultad de Enfermería, Universidad de Murcia, España. 


\section{Estudo psicossocial das consequências do trabalho dos enfermeiros hospitalares como gestão de recursos humanos}

Objetivos: analisar a relação entre as variáveis psicossociais e sociodemográficas em profissionais de enfermagem, conhecer os níveis de satisfação com o trabalho, sintomas psicossomáticos e bem-estar psicológico em enfermeiros. Metodologia: a pesquisa foi realizada com uma amostra de 476 enfermeiros (as), procedentes de nove hospitais da região de Múrcia, Espanha. Foi distribuído entre os participantes um protocolo de saúde ocupacional para preenchimento, com ferramentas para medir as variáveis psicossociais e descrever as variáveis sociodemográficas. Resultados: embora não exista alto risco de problemaspsicológicos nos sujeitos da amostra, sintomas psicossomáticos, insatisfação no trabalho e bem-estar psicológico baixo estavam presentes. Conclusões: os resultados contribuem para a investigação realizada sobre o assunto, ao identificar a presença de transtornos psicossociais nos profissionais de enfermagem, associada a condições de trabalho e determinadas variáveis psicossociais e sociodemográficas.

Descritores: Conseqüências Psicossociais; Enfermagem; Saúde Ocupacional.

\section{Estudio psicosocial de las consecuencias del trabajo de los enfermeros hospitalarios como gestión de recursos humanos}

Objetivos: Analizar la relación entre las variables psicosociales y las variables demográficas y sociolaborales en los profesionales de enfermería. Conocer los niveles de satisfacción laboral, síntomas psicosomáticos y bienestar psicológico en enfermeros. Metodología: La investigación se realizó con una muestra de 476 enfermeros/as, procedentes de 9 centros hospitalarios de la región de Murcia (España). Se distribuye entre los participantes de la muestra un protocolo de salud laboral para su cumplimentación, que contenía herramientas de medición de variables psicosociales y descripción de variables demográficas y sociolaborales. Resultados: Aunque no existe alto riesgo de problemas psicológicos en los componentes de la muestra, se presentan síntomas psicosomáticos, insatisfacción laboral, y bajo bienestar psicológico. Conclusiones: Se aportan resultados a investigaciones desarrolladas sobre el tema, al identificar la presencia de alteraciones psicosociales en profesionales enfermeros, asociado a condiciones laborales y a determinadas variables sociodemográficas y sociolaborales.

Descriptores: Consecuencias Psicosociales; Enfermería; Salud Ocupacional.

\section{Introduction}

Human resource management is fundamental in any organization because of its utility. It is applicable directly to people, or indirectly to the functions they perform or to the programs the activities they are to practice are included in.

This management is conditioned by the type of organizational system used(1). Therefore, in service organization, it is increasingly necessary to propose a theoretical model that allows us to identify and diagnose the human capital available in an organization and the results of its work.

Certain management models, like the Human System Audit or Human System Analysis Model $(\text { HSA })^{(2)}$, propose a systemic model that includes the so-called Theoretical Model of Organizational Behavior. The author of that Model $^{(2)}$ defines the quality of the human system as "the extent to which certain factors characteristic of the job organization are present, which affect people, their level of satisfaction, wellbeing and quality of life, influencing their income and the product of their work".

The repercussion the psychosocial consequences of the job environment entail can affect the health and performance of nursing staff as well as patient safety, due to the possible association between those consequences and the quality of care delivery, in the framework of Patient Safety Policies, included in the Quality Plan of the National Health System in Spain(3), elaborated as a declaration of support for the WHO Global Alliance for Patient Safety(4).

Research on safety themes is mainly focused on knowledge about and the causal identification of adverse 
events, which supposes a barrier to the adoption of solutions today(5).

The North American National Quality Forum(6) report on Safe Practices for Better Healthcare already demonstrated initial recommendations for the management and improvement of patient safety and, four years later ${ }^{(7)}$, other actions and recommendations from that report were presented with regard to patient safety.

Evidence on adverse situations and associated risk factors for patient safety in the hospital context ${ }^{(8)}$ are interpreted as the need to undertake actions that address gaps in the current health system, putting more responsibility on the shortages and organizational design of the health system than on professionals themselves ${ }^{(9)}$. Strategies like the patient classification system and its validation as an instrument to monitor the workload and identify care complexity, which enhances adverse effects, are used in countless countries, and even recommended. That is the case in Brazil(10), where the National Council of Nursing (COFEN) indicates its use as a nursing staff dimensioning instrument, despite acknowledging its slow implementation in daily professional nursing.

In the publication Nurse Staffing and Quality of Patient Care by the Agency for Healthcare Research and Quality EUA(7), a close association is manifested between the existence of appropriate nurse staffing, considering the number and type of patients (nurse/patient ratio), and the consequent appearance of stress, burnout, psychosomatic symptoms and loss of wellbeing and dissatisfaction in nursing professionals, as a risk factor that clearly affects patient safety.

Research results ${ }^{(10-12)}$ about the relation between human resource management, psychosocial consequences for workers and patient safety show increased patient morbidity and mortality rates, as well as the growing appearance of nosocomial infections(13-15). Similar studies have been undertaken in Brazil, showing the mental and physical processes hospital nurses have suffered, related to the workload and environment ${ }^{(14)}$ as well as to the management activities these professionals have assumed(16).

In the present study, we analyze psychosocial symptoms, levels of job satisfaction and psychological wellbeing as psychosocial consequences for nursing professionals working in hospitals in the Autonomous Community of Murcia. This research is justified by the close link among the organizational system of health work, the psychosocial consequences of this management system for workers and their potential repercussions for patient safety.

\section{Method}

\section{Objectives}

- To analyze the relation between the psychosocial and sociodemographic variables of nursing professionals.

- To get to know the levels of job satisfaction, psychosomatic symptoms and psychological wellbeing in nursing professionals.

\section{Sample population, origins and characteristics}

Our research was focused on 2009 and involved a population of nursing professionals from the Autonomous Community of Murcia (Spain). From this population, an incidental sample was taken from the selected hospitals. Six hundred Occupational Health Protocols were distributed for completion at nine public hospital centers. This protocol contains questions on sociodemographic and psychosocial data and includes the items of the psychosocial study variables (job satisfaction, psychosomatic symptoms and psychological wellbeing). Among the total number of protocols distributed, 457 were considered valid. The reason for excluding the remainder was the incorrect completion of the protocol.

Six out of nine hospitals in the Autonomous Community of Murcia are regional. Three of the nine institutions were located in the capital, representing $71.8 \%(n=457)$ of all participants, while the remaining $28.2 \%$ (129) came from provincial centers.

The following sociodemographic sample characteristics were considered: age, gender and marital status. The socio-employment characteristics were: time on the job, time in the hospital, contract type, work time, work journey and shift system (morning, afternoon, night), whether the workers are on duty, continuing education activities and participation in courses, congresses, clinical sessions, etc. To measure the psychosocial variables, the following tools were used:

To measure job satisfaction, the $S 10 / 12^{(17)}$ questionnaire was applied, in a previously validated version that was elaborated based on the General Satisfaction Questionnaire in Job Organizations $(\mathrm{S} 4 / 82)^{(18)}$, showing improvements in six exclusive criteria, two related to the relevance and pertinence of the item across roles and organizations; another to its relation with the global satisfaction construct; and three to its criterion validity. As a result of this process, the $\mathrm{S} 10 / 12$ questionnaire was elaborated. The contents of its 12 items are relevant for any organizational role in any 
organization and valued on a seven-point Likert scale (from 1 to 7), ranging from "very dissatisfied" to "very satisfied", and covers three dimensions: a) "Satisfaction with supervision or superiors". b) "Satisfaction with the work means and context, its physical environment, characteristics and existing spaces". c) "Satisfaction with compensations received in the work sphere".

To measure psychosomatic symptoms associated with stress in the work environment, we used the Golembiewski scale, adapted from Hock(19). This scale consists of 12 items, and answers are valued on a response scale ranging from 0 to 6 , between "never" and "very frequently", with a maximum score of 72 .

For the level of psychological wellbeing, Goldberg's General Health Questionnaire GHQ-28(20) was used, adapted and validated by Lobo, Pérez Echeverria and Artal(21), which assesses the participants' general health measure through 28 items, which are scored on a fourpoint Likert scale (from 0 to 3), distributed among four subscales with seven items each.

These subscales allow us to get to know the four dimensions in which individuals can suffer: "Somatic symptoms", "anguish/insomnia", "Social dysfunction" and "Severe depression".

\section{Data collection and analysis procedure}

SPSS statistical software for Windows was used. The variables were subject to descriptive analysis; bivariate and multivariate analyses were applied between the psychosocial, sociodemographic and socio-employment variables; as well as the analysis of absolute frequencies and percentages for psychosocial, sociodemographic and socio-occupational variables. Means and standard deviations were calculated. Cronbach's alpha was used to determine the reliability of each scale and subscales of all questionnaires. The relation between each of the psychosocial variables is established through Pearson's chi-square statistics. The association between the psychosocial variables and the other sociodemographic and socio-employment variables was analyzed. Correlations were determined through Pearson's chi-square, one-factor ANOVA for qualitative variables, and Student's T-test for quantitative variables.

\section{Results}

\section{Sociodemographic and socio-employment variables}

Participants' ages $(n=457)$ range between 22 and 63 years, with a mean age of 40 years. Twenty-nine percent is between 20 and 34 years old $(n=131), 29$ of whom are men $(22.3 \%)$ and $102(n=31.8 \%)$ women. A significant different was found in terms of age-gender variables $(p<0.05)$

As regards gender, $71.3 \%$ of the sample $(n=457)$ is female $(n=326)$ and $28.7 \%(n=131)$ male

With regard to marital status, the highest frequencies are found for "married or living with a fixed partner" ( $n=301)$ with 68.4\%, "single" $(n=97)$ with $21.3 \%$, and the lowest frequency for "widowed, separated / divorced" ( $n=47)$ with 10.3\%. Among men, $79.4 \%$ are married $(n=104)$ and, among women, $63.9 \%$ $(n=207)$. On the opposite, there are more single $(23.5 \%$ women and $16 \%$ men) and divorced/separated women than men ( $12.7 \%$ women and $4.6 \%$ men). As regards marital status and gender variables, a statistically significant difference is observed $(p<0.05)$

\section{Socio-employment variables}

Time on the job: The mean time on the job is 12.14 years, ranging between one and 35 years, with a standard deviation of 8.61 . A majority $(n=136)$ of participants in the total sample $(n=445)$ has less than six years on the job (29.8\%).

As regards gender differences, a higher percentage is found for women with five years on the job (32.6\%) when compared to men $(25.6 \%)$, but the comparison of distributions through the chi-square test does not reveal significant differences between men and women $\left(\chi^{2}=5.09 ;\right.$ n.s.; $\left.p=0.078\right)$.

Time in the company: The mean company time is 16.9 years, ranging from one to 35 , with a standard deviation of 9.19. The most numerous sample group $(n=84)$ has worked at the company for less than 11 years $(18.4 \%)$. A higher percentage of women with 35 years or more of company time (2.9\%) was found when compared to men (1.6\%). The chi-square test, applied to discover any association between gender and company time showed no statistically significant result $\left(\chi^{2}=8.73 ;\right.$ n.s. ; $\left.p=0.27\right)$.

Contract type: $83.7 \%$ of sample participants is working on an indefinite contract $(n=342), 11.2 \%$ on a temporary contract $(n=46)$ and $5.1 \%$ were hired as substitutes $(n=21)$. Among temporary contracts, with $46(11.2 \%), 12.1 \%$ correspond to women $(n=35)$ and $9.2 \%$ to men $(n=11)$. The lowest frequency is found for replacements with 21 contracts $(5.1 \%), 6.6 \% \quad(n=19)$ referring to women and $1.7 \%(n=2)$ to men.

The chi-square test, applied to look for associations between gender and contract type, showed no statistically 
significant association ( $\chi^{2}=5,09 ;$ n.s.; $p=0.078$ )

Work time: Among the 457 sample participants, 394 valid answers were obtained, 56.60\% $(n=223)$ indicating daytime, 15 (3.8\%) nighttime work, while the remaining 156 participants (39.6\%) work during both periods. The daytime period corresponds to $57.6 \%$ of women and $54.2 \%$ of men. The shifts that vary between day and nighttime involve $40.2 \%$ of women $(n=111)$ and $38.1 \%$ of men $(n=45)$. The clearest difference is noted in the nighttime period though, which involves $2.2 \%$ of women but $7.6 \%$ of men. The chi-square test, applied to prove the association between gender and work time, showed a statistically significant result. Thus, it can be concluded that gender is related with work time $\left(\chi^{2}=6.71 ; \mathrm{p}<0.035\right)$

Work journey: $96.3 \%$ of the sample $(n=389)$ has a continuous work journey and $3.7 \%(n=15)$ a split work journey. No significant differences between gender and type of journey was found in the distribution of the data $\left(\chi^{2}=1.34 ; p=0.510\right)$.

Shift work: $66.7 \%(n=297)$ of the sample $(n=445)$ does not work shifts, while 33.3\% $(n=148)$ does.

No significant difference exists between gender and work shift $\left(\chi^{2}=1.64 ; p=0.199\right)$

Being on duty: $35.6 \%(n=144)$ of the sample is sometimes on duty, 100 of whom are women (35.1\% of women) and 44 men (36.7\% of men); $64.4 \%(n=261)$ does not. The comparison of distributions through the chi-square test shows no significant differences between men and women ( $\chi^{2}=0.92 ;$ n.s.; $\left.p=0.762\right)$.

Participation in continuing education: $66.3 \%$ $(n=303)$ of the total sample takes part in continuing education, while the remaining $33.7 \%(n=154)$ does not. With respect to this variable and the gender variable, the comparison of distributions through the chi-square test shows significant differences between men and women $\left(\chi^{2}=4.00 ; p=0.045\right) .63 .5 \%$ of all women $(n=207)$ and $73.3 \%$ of all men $(n=96)$ participate in continuing education activities.

Training activities: courses, congress participation, recycling sessions, clinical sessions: When specifying training activities, $58.4 \%$ of the sample participates in training courses, while $41.6 \%$ does not. The comparison of distributions through the chi-square test shows no significant differences between both variables $\left(\chi^{2}=3.15\right.$; n.s.; $\mathrm{p}=0.76$ )

With respect to congress participation, on the opposite, only $33.3 \%$ of the sample participates, while $66.7 \%$ does not. As regards this variable and gender differences, $42 \%$ de hombres watch congresses, against
$29.8 \%$ of women, and significant differences in data distribution were found $\left(\chi^{2}=6.29 ; p=0.012\right)$.

As for participation in recycling sessions, $29.4 \%$ participates while $75.1 \%$ does not. Concerning this variable and gender, $35.9 \%$ of men and $20.6 \%$ of women participate, and significant differences in data distribution are found $\left(\chi^{2}=11.72 ; p=0.001\right)$. Finally, as part of this continuing education variable, $17.7 \%$ participate in clinical sessions while $82.3 \%$ does not. No statistically significant association exists in the distribution of these variables $\left(\chi^{2}=3.37 ; p=0.066\right)$

\section{Measurement of psychosocial variables}

As regards Job satisfaction, the $S 10 / 12^{(17)}$ questionnaire consists of three dimensions: Satisfaction with supervision, with the physical environment and with the compensations received.

Concerning "Satisfaction with supervision or supervisors", results show a mean score of 4.89 , with a standard deviation of 1.25 . The maximum score is seven and the minimum one, with a reliability ratio of 0.919 .

$11.8 \%$ of participants are dissatisfied with their work, while $67.8 \%$ is satisfied. The mean score for "Satisfaction with the physical environment" is 4.05 , with a standard deviation of 1.22 and a reliability ratio of 0.734 . Scores range from 1.50 to 7 . As for "satisfaction with compensations received", the mean score is 4.17 , with a standard deviation of 1.45 , a reliability ratio of 0.888 and a score range between 1 and 7. The mean score for "Total satisfaction" is 4.50 , with a standard deviation of 1.06 and a reliability ratio of $0.898 .15 .6 \%$ of participants are dissatisfied with their work while $53.1 \%$ is satisfied. $31.3 \%$ is neither satisfied nor dissatisfied.

When measuring the association between psychosomatic symptoms and stress level, the results obtained in the sample $(n=446)$ show a mean score of $29.33 \%$, against a maximum of 72 and a standard deviation of 10.89 .

To measure Psychological wellbeing, the questionnaire consists of 28 items with four alternative answers, measuring four dimensions of psychological wellbeing: 1) somatic symptoms, 2) anguish and insomnia, 3) social dysfunction and 4) severe depression, with seven items each. The results corresponding to "somatic symptoms" (GHQ-A) show a mean score of $6.61(n=450)$, against a maximum score of 21 and a standard deviation of 4.26 . The reliability ratio is 0.888 . In the "anguish/insomnia" dimension (GHQ-B), the results show a mean score of $6.10(n=449)$, standard deviation of 4.22 and reliability ratio of 0.893 , showing 
no influence on absolute wellbeing for $30.7 \%$, while $69.3 \%$ felt anguish and insomnia. Nobody reached the maximum score of 21 , which would indicate the lowest level of psychological wellbeing on this scale. In the "social dysfunction" dimension (GHQ-C), the mean score is 7.24 and the standard deviation 2.40, with a reliability ratio of $0.785 .4 .4 \%$ of the sample shows a better than normal psychological wellbeing in this dimension, and the remaining $95.6 \%$ has been victim of social dysfunction. In the "severe depression" dimension" (GHQ-D), the results show a mean score of 1.77 and a standard deviation of 3.15 , with a reliability ratio of $0.905 .84 .3 \%$ of the sample demonstrates a better than normal psychological wellbeing, while the remaining $15.7 \%$ manifests reduced wellbeing due to severe depression. The psychological wellbeing results on the "global scale" show a mean score of 21.75 and a standard deviation of 11.35 . The highest score indicates the lowest wellbeing. The reliability ratio corresponds to 0.936. On the global scale, reminding that the cut-off point is seven or higher, it is observed that three percent of the sample does not experience any psychological wellbeing problems, while $97 \%$ does. Among the four subscales, the GHQ_D subscale, "severe depression", shows the lowest mean score, translated as greater psychological wellbeing, followed by GHQ_B, related to the "anguish and insomnia" dimension". Scales GHQ_A and GHQ_C, "somatic symptoms" and "social dysfunction", respectively, manifest the lowest level of psychological wellbeing, with higher mean scores.

\section{Correlation between psychosocial variables}

The psychosocial variables show a significant difference $(p<0.05)$. A significant inverse linear correlation is observed among total satisfaction, psychosomatic symptoms and Total GHQ, which indicates that increased satisfaction is associated with a drop in the other psychosocial indicators. On the opposite, all indicators of the remaining variables show significant positive mutual correlations.

\section{Sociodemographic and socio-employment variables related to psychosocial indicators}

To obtain these data, we have used bivariate correlation analysis to establish the association between each of the psychosocial variables and the sociodemographic and socio-employment variables (age, time on the job and company time).

Student's t-test was applied to the association between two-level psychosocial and qualitative variables or possible answers (gender, shift work, on duty, continuing education), and one-factor ANOVA to check for significant differences in psychosocial variables and qualitative variables with three alternative answers (work journey, contract type, work type, marital status).

As regards marital status-psychosocial variables, the highest mean score for job satisfaction corresponds to single participants in the sample and the lowest to separated or divorced participants $(f=0.64 ; p>0.05)$. The latter also obtain a higher mean score on psychosomatic symptoms $(f=0.53 ; p>0.05)$ and the lowest mean score on psychological wellbeing $(f=2.22 ; p>0.05)$, while single participants again show the lowest score on these variables. No significant differences exist in the variables under analysis in function of the participants' marital status.

Work time-psychosocial variables: In the alternative answers about the work time (daytime, nighttime or both), the highest mean satisfaction score relates to participants who work daytime and the lowest to those working at $(\mathrm{f}=2.06 ; \mathrm{p}>0.05)$. Levels of psychological wellbeing are higher among participants working both shifts and lower among those working night shifts $(\mathrm{f}=0.31 ; \mathrm{p}>0.05)$

Work journey- psychosocial variables: Between the two alternative answers (continuous or split journey), participants working continuous journeys obtain a higher mean satisfaction score $(t=.332 ; \mathrm{p}=0.001)$ but, in turn, also display more psychosomatic symptoms $(\mathrm{t}=.117$; $p>0.05)$ and less psychological wellbeing $(t=.068$; $p>0.05)$. A significant difference $(p<0.05)$ is observed for the variable "job satisfaction" $(p=0.001)$.

Contract type- psychosocial variables: As regards the contract type (indefinite, temporary or replacement), lower psychological wellbeing scores are observed among participants working on an indefinite contract. Participants working on a temporary contract obtain the lowest mean satisfaction score (least satisfied) but, in turn, show the lowest mean scores on psychosomatic symptoms. Professionals working on a replacement contract show the highest mean satisfaction (most satisfied), lowest mean wellbeing (more psychological wellbeing), despite some specific and concrete psychosomatic symptoms. No statistically significant differences exist for any of the variables in function of the contract type.

Shift work- psychosocial variables: As regards to whether the professionals do shift work or not, the higher mean satisfaction score indicates that satisfaction levels are higher among professionals not doing shift 
work $(t=2,31 ; p=0.021)$, but these also obtain higher mean scores on psychosomatic symptoms $(t=1.33$; $p>0.05)$ and psychological wellbeing ( $t=.527 ; p=596)$, which means a lower level of psychological wellbeing. The difference in the satisfaction variable $(p=0.021)$ is statistically significant $(\mathrm{p}<0.05)$.

Gender- psychosocial variables: The association between gender and psychosocial variables shows a higher mean score, or greater satisfaction, among women ( $\mathrm{t}=-.170 ; \mathrm{p}>0.05)$ Also, higher mean scores are observed for psychosomatic symptoms ( $t=-$ $4.31 ; p=0.000)$ and psychosocial wellbeing $(t=-$ 3.26; $p=0.000$ ) among women, which means "less psychological wellbeing" when compared to men. A statistically significant difference with regard to gender is observed for psychological wellbeing and psychosomatic symptoms $(p<0.05)$.

On Duty-psychosocial variables: As to whether they are sometimes on duty, higher mean scores are found among professionals who do not $(t=-393 ; p>0.05)$, as well as lower mean scores on psychosomatic symptoms $(t=1.05 ; p>0.05)$. Participants who are sometimes on duty, in turn, reveals lower mean scores for psychological wellbeing, that is, greater psychological wellbeing $(t=.373 ; p>0.05)$.

Table 1 - Association among variables

\begin{tabular}{|c|c|c|c|c|c|c|}
\hline & \multicolumn{2}{|c|}{ Satisfaction } & \multicolumn{2}{|c|}{ Psychosomatic symptoms* } & \multicolumn{2}{|c|}{ Psychological wellbeing* } \\
\hline & More & Less & More & Less & More & Less \\
\hline Gender & Woman & Man & Woman & Man & Man & Woman \\
\hline Age & $22 / 25$ & $30 / 35$ & $30 / 35$ & $22 / 25$ & $22 / 25$ & $35 / 40$ \\
\hline Marital status & Single & Separated & Separated & Single & Single & Separated \\
\hline Time on the job & 1 to 5 & 30 to 35 & 20 to 25 & 1 to 5 & 15 to 20 & 25 to 30 \\
\hline Time in the company & 1 to $5^{\dagger}$ & 10 to $15^{\dagger}$ & 10 to 15 & 30 to 35 & 1 to 5 & $>30$ \\
\hline Work time & Day & Both & Day & Night & Night & Both \\
\hline Type of journey & Continuous $^{\ddagger}$ & Not continuous $\ddagger$ & Continuous & Not continuous & Not continuous & Continuous \\
\hline Shifts & $\mathrm{No}^{\S}$ & Yes $^{\S}$ & Yes & No & Yes & No \\
\hline Duty & No & Yes & Yes & No & No & Yes \\
\hline Education & Yes & No & No & Yes & Yes & No \\
\hline Type of Contract & Replacement $^{*}$ & Temporary* & Replacement & Temporary & Replacement & Indefinite \\
\hline
\end{tabular}

* $\mathrm{P}=0.000 ;+\mathrm{P}=0.012 ; \neq \mathrm{P}=0.001 ; \S \mathrm{P}=0.021$

\section{Discussion}

Results concerning satisfaction levels are in accordance with other authors' contributions(16-17,21-25) about the feelings and emotions workers feel towards their work, with regarding to the pleasure or displeasure subjects feel towards what they do and their personal relations in their workplace. This refers to their perception of their role they play, in combination with how they are acknowledged and treated in the company, in
Access to continuing education- psychosocial variables: what this variable is concerned, greater satisfaction ( $t=4.67 ; p=0.000)$ and greater psychological wellbeing $(t=-1.42 ; p>0.05)$ are found among sample members who have access to continuing education. Professionals who do not have access reveal more psychosomatic symptoms $(t=-.983 ; p>0.05)$ when compared to other participants.

Correlation between quantitative, sociodemographic and socio-employment variables (age, time on the job and company time) and psychosocial variables

The correlation between psychosocial variables and the age variable shows no significant difference $(P<0.05)$. Similarly, there is no significant difference between psychosocial variables and the time on the job variable. Only one significant difference $(p<0.05)$ was found between company time and total satisfaction, but not between company time and the other psychosocial variables.

With a view to a further understanding, the following table summarizes the association between variables and greater or lesser job satisfaction, presence of psychosomatic symptoms and state of wellbeing (Table 1 ). 
superiors, need to help workers in case of organizational or other changes. Superiors' non-reciprocity towards workers, due to non-recognition of their work and unfair treatment, is a cause of job dissatisfaction. This nonreciprocity of superiors towards their subordinates' work arouses negative behavioral changes, aggressiveness and loss of personal resources in workers. As regards stress measurement and consequent psychosomatic symptoms, in other studies(23-26), the appearance of stress-related psychosomatic symptoms and consequent job dissatisfaction among health professionals is due to the generalized social idea that sometimes exists about health professionals to address problems that are hard to solve. This generates depersonalization, stress, psychosomatic symptoms and job dissatisfaction among workers. Fatigue and extreme tiredness, which appears as the main psychosomatic symptoms in our sample, coincides with other abovementioned authors' assertions, consequently entailing chronic conditions, although other studies defend that, although stress and its coping can influence people's health conditions and the appearance of psychosomatic symptoms, it has not been demonstrated that it causes certain diseases. Our results support assertions about the relation between psychosomatic symptoms and certain socio-employment and sociodemographic variables: women present more psychosomatic symptoms $(p<0.05)$, who are mainly separated and divorced and mostly between 30 and 35 years of age. As regards psychological wellbeing, the present study results are in line with authors who manifest the existing relation between certain job factors and their psychosocial consequences for workers' health, satisfaction and wellbeing(23-26). In our sample, results evidences that "social dysfunction" is one of the dimensions that most presents problems related to wellbeing, that health and social service workers act more emotionally in their professional activity when compared to other professional groups who behave rationally and get less involved in help relations and less physically and mainly psychologically exhausted. It is no coincidence therefore that the item showing the lowest psychological wellbeing score in this dimension is "Does it take you more time to do things?", related to job performance.

\section{Conclusions}

As the main conclusion for the advancement of scientific knowledge, we can affirm that its results have offered new data in the research developed by the Region of Murcia and the Spanish Ministry of Health and Consumption "Indicators of best practices in patient safety", as well as in the achievement of the qualitative research project "Participatory evaluation of the nursing team work process at a hospital in Murcia (Spain)", in cooperation with the Nursing Department at the Brazilian Federal University of Pelotas (UFP), produced based on the quantitative results obtained in the present study, as part of the University of Murcia Nursing Department's research area "Health service administration and quality management. Psychological factors related to occupational health and human resource management", funded by a Carolina Grant at the Federal University of Pelotas. This project started in the context of a Framework Cooperation Agreement closed between both universities.

In conclusion, in this study, we highlight the presence of Psychosomatic Symptoms, Job dissatisfaction and Psychological wellbeing problems, associated with somatic symptoms and social dysfunction. The psychosocial consequences of work affect job performance and absenteeism. Participants are satisfied with their good relations with superiors but, at the same time, perceive that they are treated and recognized unfairly with regard to the role they play. At the same time, they take great interest in work and are motivated by the achievement of objectives. They manifest dissatisfaction with their work conditions, considering the physical space and work environment. Psychosocial consequences were verified in view of the impossibility to participate in continuing education. The professional stability of an indefinite job contract does not correspond to professional wellbeing and satisfaction. Shift work, night work and changing work times are associated with psychosocial consequences. The professional's family situation, age, time on the job and company time entail psychological consequences. Differences between men and women need further research, considering certain job and demographic conditions, due to the psychosocial consequences verified among women. The psychosocial consequences of work for Nursing professionals affect their health levels and job performance. The association between the psychosocial consequences for Nursing professionals and patient morbidity and mortality levels needs to be investigated. We will propose the inclusion of these psychosocial consequences of work as Patient Safety indicators. 


\section{References}

1. Raventos Joseph. Es hoy determinante invertir en el desarrollo de las organizaciones? Capital Humano. octubre 2004;(181):16-8.

2. Quijano S, Navarro J, Yepes M, Berger R, Romeo M. La Auditoría del Sistema Humano (ASH) para el análisis del comportamiento humano en las organizaciones. Papeles del Psicólogo. 2008;29(1):92-106.

3. Estudio Nacional sobre los Efectos Adversos ligados a la Hospitalización. Madrid; 2006. Madrid: Ministerio Sanidad y Consumo; 2005. ENEAS Informe (Es).

4. Calidad de la atención: seguridad del paciente. 55a Asamblea Mundial de la Salud A55/13. 23 de marzo de 2002. OMS: Informe de la Secretaría OMS; [acesso 8 jun 2012]; Disponivel em: http://www.who.int/gb/ ebwha/pdf_files/WHA55/sa5513.pdf.

5. Martínez Ques AA. ¿Quién se ocupa de la seguridad de los pacientes? Rev Evidentia. [periódico na Internet]. ene-feb 2007;4(13). [acesso 18 maio 2012]; Disponível em:Disponible en: http://www.index.com

6. National Quality Forum: Safe Practices for Better Healthcare. A Consensus report. NQF. Washington; 2003. 7. National Quality Forum. Safe Practices for Better Healthcare 2006 update. (NQF), Washington: The National Quality Forum [Internet]. 2007; [acesso 10 marzo 2012]; Disponivel em: http://www. msc.es/organizacion/sns/planCalidadSNS/docs/ construccionValidacionIndicadoresSeguridadPaciente.pdf 8. Silva AEB de C, Reis AMM, Miasso AI, Santos JO, Cassiani $\mathrm{SH}$ De B. Eventos adversos causados por medicamentos en un hospital centinela del Estado de Goiás, Brasil. Rev. Latino-Am. Enfermagem. [periódico na Internet]. 2011; 19(2) [acesso 14 sept. 2012]; 378-86. Disponível em: <http://www.scielo.br/scielo.php?script=sci_ arttext\&pid=S0104-11692011000200021\&lng=pt\&nr $\mathrm{m}=$ iso $>$. ISSN 0104-1169. http://dx.doi.org/10.1590/ S0104-11692011000200021.

9. López Montesinos $M J$, Guerrero Fernández $M$, Martínez Fresneda M, Cortés Angulo J. Intervención para la disminución de las estancias inapropiadas. Un estudio de tres años en un hospital universitario. Evaluación mediante empleo de Appropiateness evaluatión protocol (AEP). Rev Gestión Hospitalaria. 2003;14(1):99-107.

10. Perroca MG. Desarrollo y validación de contenido de la nueva versión de un instrumento para clasificación de pacientes. Rev. Latino-Am. Enfermagem. [periódico na Internet]. 2011;19(1); [acesso 14 sept 2012];58-66. Disponível em: <http://www. scielo.br/scielo.php?script $=$ sci_arttext\&pid=S0104-
$11692011000100009 \&$ Ing $=p t \& n r m=i s o>$.

ISSN

0104-1169. http://dx.doi.org/10.1590/S010411692011000100009.

11. Aiken LH, Mullin M. Hospital con Magnetismo: un mecanismo de organización para mejorar los resultados de los pacientes. Enferm Clín. 1995;5(6):35-8.

12. Aiken LH, Clarke SP, Sloane DM. Hospital staffing, organization, and quality of care: Cross-national findings. Int J Qual Health Care. 2002;14(1):5-13.

13. Urbanetto Janete de Souza et al. Estrés en el trabajo de enfermería en hospital de emergencia: análisis usando la Job Stress Scale. Rev. Latino-Am. Enfermagem. [periódico na Internet]. 2011;19(5). [acesso 14 sept 2012];1122-31. Disponível em: <http://www.scielo.br/scielo.php?script=sci_ arttext\&pid=S0104-11692011000500009\&Ing=pt\&nr m=iso>. ISSN 0104-1169. http://dx.doi.org/10.1590/ S0104-11692011000500009.

14. Mininel VA, Baptista PCP, Felli VEA. Cargas psíquicas y procesos de desgaste en trabajadores de enfermería de hospitales universitarios brasileños. Rev. Latino-Am. Enfermagem. [periódico na Internet]. 2011;19(2). [acesso 14 sept 2012]; 340-7 . Disponível em: <http://www.scielo.br/scielo.php?script=sci_ arttext\&pid =S0104-11692011000200016\&lng =pt\&nr $\mathrm{m}=\mathrm{iSo}>$. ISSN 0104-1169. http://dx.doi.org/10.1590/ S0104-11692011000200016.

15. Moncada S, Llorens C, Navarro C, Kristensen, TS. Versión en lengua castellana del Cuestionario Psicosocial de Copenhague (COPSOQ). Arch Prevención Riesgos Laborales. 2005;8(1):18-29.

16. Guerra ST, Prochnow AG, Trevizan MA, Guido $L$ de A. El conflicto en el ejercicio gerencial del enfermero en el ámbito hospitalario. Rev. Latino-Am. Enfermagem. [periódico na Internet]. 2011;19(2). [acesso 14 sept 2012];362-9 . Disponível em: <http://www. scielo.br/scielo.php?script=sci_arttext\&pid=S0104$11692011000200019 \&$ Ing $=$ pt\&nrm $=$ iso $>$.

ISSN

0104-1169. http://dx.doi.org/10.1590/S010411692011000200019.

17. Meliá JL, Peiró JM. El Cuestionario de Satisfacción S10/12: Estructura factorial, fiabilidad y validez. Rev Psicol Trabajo Org. 1989;4(11):179-87.

18. Meliá JL, Peiró JM, Calatallud C. El Cuestionario General de Satisfacción Laboral en contextos organizacionales laborales. Estudios factoriales, fiabilidad y validez (presentación del cuestionario S4/82). Millars. 1986;9:43-77.

19. Hock RR. Professional burnout among public school teachers. Public Personnel Manage. 1988;17(2):167-89. 
20. Goldber DP, Hillier VF. A scaled version of the General Health Questionnaire: Psychological Health Questionnaire: Psychol Med. 1979;27:191-7.

21. Lobo A, Pérez-Echeverría MJ, Artal J. Validity of the scaled version of the General Health Questionnarie (GHQ-28) in a Spanish population. Psychol Med. 1986;16:135-40.

22. Herzberg F, Mausner B, Snyderman BB. The Motivation to work. Nueva York: John Wiley; 1959.

23. Shimizu HE; Couto DT, Merchan-Hamann E. Placer y sufrimiento en trabajadores de enfermería de una Unidad de Terapia Intensiva. Rev. Latino-Am. Enfermagem. [periódico na Internet]. 2011;19(3); [acesso 14 sept 2012];565-72. Disponível em: <http://www.scielo.br/scielo.php?script=sci_ arttext\&pid=S0104-11692011000300016\&lng=pt\&nr $\mathrm{m}=$ iso $>$. ISSN 0104-1169. http://dx.doi.org/10.1590/ S0104-11692011000300016.

24. Negeliskii C, Lautert L. Estrés laboral y capacidad para el trabajo de enfermeros de un grupo hospitalario. Rev. Latino-Am. Enfermagem. [periódico na Internet]. 2011;19(3); [acesso 14 sept 2012];606-13 . Disponível em: $\quad<$ http://www.scielo.br/scielo.php?script $=$ sci_ arttext\&pid =S0104-11692011000300021\&lng=pt\&nr $\mathrm{m}=$ iso $>$. ISSN 0104-1169. http://dx.doi.org/10.1590/ S0104-11692011000300021.

25. Rodrigues VMCP, Ferreira AS de S. Factores generadores de estrés en enfermeros en unidades de terapia intensiva. Rev. Latino-Am. Enfermagem. . [periódico na Internet]. 2011;19(4); [acesso 14 sept 2012];1025-32 . Disponível em: http://www. scielo.br/scielo.php?script=sci_arttext\&pid=S0104$11692011000400023 \&$ lng $=p t \& n r m=$ iso $>$. ISSN 0104-1169. http://dx.doi.org/10.1590/S010411692011000400023.

26. Melo MB de, Barbosa MA, Souza PR de. Satisfacción en el trabajo del equipo de enfermería: revisión integradora. Rev. Latino-Am. Enfermagem [periódico na Internet]. 2011;19(4); [acesso 14 sept 2012];1047-55 . Disponível em: $\quad<h t t p: / / w w w . s c i e l o . b r / s c i e l o . p h p ? s c r i p t=s c i$ arttext\&pid =S0104-11692011000400026\&lng=pt\&nr $\mathrm{m}=$ iso $>$. ISSN 0104-1169. http://dx.doi.org/10.1590/ S0104-11692011000400026. 